\title{
KEMAMPUAN GURU DALAM PEMBELAJARAN PENDIDIKAN KEWARGANEGARAAN DI SMP NEGERI KOORDINATOR WILAYAH SLEMAN TENGAH
}

\author{
Endang Purwanti, Anik Ghufron \\ SMP Negeri 2 Tempel Kabupaten Sleman, PPS UNY \\ ipung_end@yahoo.co.id, anikghufron@uny.ac.id
}

\begin{abstract}
Abstrak
Tujuan penelitian adalah mendeskripsikan: (1) kemampuan guru Pendidikan Kewarganegaraan di SMP Negeri Koordinator Wilayah Sleman Tengah dalam melaksanakan pembelajaran (2) faktor penghambat dan pendukung guru Pendidikan Kewarganegaraan di SMP Negeri Koordinator Wilayah Sleman Tengah dalam melaksanakan pembelajaran secara profesional. Metode penelitian mengguna-kan jenis penelitian kualitatif. Subjek penelitian guru Pendidikan Kewarganegaraan 5, Kepala Sekolah 3, guru mata pelajaran lain 9, siswa 6 serta pengawas 1 . Teknik pengumpulan data: pengamatan parti-sipasi, wawancara mendalam, dan dokumentasi. Analisis data menggunakan model kualitatif-interaktif. Hasil penelitian: (1) kemampuan guru Pendidikan Kewarganegaraan di SMP Negeri Koor-dinator Wilayah Sleman Tengah dalam pembelajaran kurang. Penyusunan RPP belum serius. Pelaksa-naan pembelajaran didasarkan kebiasaan guru mengajar. Guru belum berperan sebagai pendidik, inovator, dan teladan. Penilaian berbentuk ulangan harian, ujian mid semester dan ujian semesteran, belum mengembangkan instrumen penilaian. (2) Hambatan internal terbatasnya wawasan materi PKn, lemahnya motivasi mempelajari bahan ajar, komitmen belum kuat, terbatasnya pengalaman mengikuti forum ilmiah. Hambatan eksternal terbatasnya media pembelajaran di sekolah. Media pembelajaran kurang menarik ditampilkan di kelas. Keterbatan di sekolah adalah sumber bahan ajar.
\end{abstract}

Kata kunci; kemampuan guru, mata pelajaran PKN, pembelajaran

\section{THE TEACHER CAPABILITIES IN CITIZENSHIP EDUCATION SUBJECTS LEARNING AT STATE JUNIOR HIGH SCHOOL OF REGION COORDINATION SLEMAN TENGAH}

\begin{abstract}
The purpose of this study was to determine: (1) the ability of Citizenship Education subject teachers at State Junior High School of Region Coordination Sleman Tengah in the learning imple-mentation, and (2) the inhibiting and supporting factors of Citizenship Education subject teachers at Junior High School of Region Coordination Sleman Tengah in the professional learning implemen-tation. The methods used was qualitative research. The subjects were 5 Citizenship Education Teach-ers, 3 School Principals, 9 teachers of other subjects, 6 students and 1 inspector. Data collection techniques used were participation observation, interviews, and documentation. Data analysis used was interactivequalitative model. The results: (1) the ability of Citizenship Education teachers at Junior High School of Region Coordination Sleman Tengah in learning activities implementation were poor. The implementation of the restructuring plan have not done seriously. The learning imple-mentation is based on daily habits. Teachers have not been able to play of roles such as educators, innovators, and model. The evaluation of daily tests, mid semester and semester tests, but unfamiliar with Citizenship Education subjects development assessment instruments. (2)the internal constraints consisted of poor knowledge of Citizenship Education subject, poor motivation to learn teaching material, weak commitment of Citizenship Education subject teachers in carrying out good teachers, and the limited experience in pursuing scientific forum. The external constraints were limited Citizen-ship Education media learning in school. The learning media were less attractive viewed to be displayed in the classroom. Limited resources of teaching materials in the school.
\end{abstract}

Keywords: teacher capability, Citizenship Education, learning 


\section{Pendahuluan}

Guru mempunyai fungsi, peran dan kedudukan yang sangat strategis dalam rangka mewujudkan tujuan, fungsi dan visi pendidikan nasional. Untuk menjawab tantangan jaman, menurut pasal 4 Undang Undang Nomor 14 tahun 2005 tentang Guru dan Dosen peran guru sebagai agen pembelajaran berfungsi untuk meningkatkan mutu pendidikan. Maka guru harus mampu menciptakan pembelajaran yang menggairahkan, membangkitkan minat belajar dan menyenangkan. Untuk itu diperlukan guru yang kreatif, profesional dan menyenangkan.

Metode mengajar menurut Sanjaya (2009, p.125) di antaranya adalah ceramah, dis-kusi, demonstrasi, simposium dan simulasi. Metode ceramah dapat diartikan sebagai cara menyajikan pelajaran melalui penuturan secara lisan atau penjelaskan langsung kepada sekelompok siswa. Metode demonstrasi adalah metode penyajian pelajaran dengan memperagakan dan mempertunjukkan kepada siswa tentang suatu proses, situasi atau benda tertentu, baik sebenarnya atau hanya sekedar tiruan. Diskusi bersifat bertukar pikiran dan pengalaman untuk menentukan keputusan tertentu secara bersama-sama (Sanjaya, 2009, p.154). Sebagai metode mengajar, simulasi dapat diartikan cara penyajian pengalaman belajar dengan menggunakan si-mulasi tiruan untuk memahami tentang konsep, prinsip, atau keterampilan tertentu. Metode dan strategi barupun lahir seiring dengan perkembangan ilmu pendidikan itu sendiri, seperti metode pembelajaran portofolio dan strategi pembelajaran kontekstual (contextual teaching and learning atau CTL). Metode pembelajaran PKn yang buruk ialah bahwa para guru umumnya menggunakan metode ceramah dan tanya jawab dengan pemberian tugas (Samsuri, 2011, p.4). Dalam pembelajaran PKn, penggunaan alat peraga sangat minim dan terbatas pada pembelajaran model talk dan chalk (hanya ceramah dan menulis di papan tulis).

Guru juga harus memiliki standar kompetensi yang dikembangkan secara utuh dari empat kompetensi utama, yaitu kompetensi pedagogik, kepribadian, sosial, dan profesional. Keempat kompetensi tersebut terintegrasi dalam kinerja guru. Guru akan terus meningkat kemampuannya apabila memiliki keinginan untuk selalu menambah pengetahuan dan pemahaman berbagai strategi manajemen pembelajaran dan perilaku dan tahu bagaimana menggunakan dan beradaptasi dengan para siswa, termasuk bagaimana untuk personalisasi pembelajaran untuk memberikan kesempatan bagi semua peserta didik untuk mencapai potensi mereka (Training and Development Agency for Schools', 2007).

Seorang guru yang berpengalaman sinonim dengan guru yang memiliki kinerja yang baik yaitu mampu secara efektif dan efisien mengajar di kelas dan menjamin adanya transfer materi pendidikan (Cheng, et al, 2002, p.15). Pullias dan Young (1988), Manan (1990), serta Yelon dan Weinstein (dalam Mulyasa, 2009, p.37) mengidentifikasi sedikitnya 19 peran guru yakni guru sebagai pendidik, pengajar, pembimbing, pelatih, penasehat, pembaharu (innovator), model dan teladan, pribadi, peneliti, pendorong kreativitas, pembangkit pandangan, pekerja rutin, pemindah kemah, pembawa ceritera, aktor, emansipator, evaluator, pengawet dan sebagai kulminator. Dengan profesionalisme guru maka guru masa depan tidak tampil lagi sebagai pengajar (teacher), seperti fungsinya yang menonjol selama ini, tetapi beralih sebagai pelatih (coach), pembimbing (counselor) dan manajer belajar (learning manager). Berbagai kompetensi tersebut, dalam konteks pembelajaran bermuara pada kemampuan guru dalam merencanakan pembelajaran, melaksanakan pembelajaran, dan evaluasi pembelajaran.

Perencanaan berarti mendisain pembelajaran yang efektif, mendesain pengembangan pembelajaran, dan mendesain kemajuan dan mengkonsolidasikan pembelajaran (Chambers, 2008, p.47). Perencanaan pembelajaran juga harus memperhatikan apa yang dipelajari. Misalnya 
dalam merencanakan pembelajaran interdisipliner, dapat dimulai dengan memilih konteks tertentu, komunitas atau peristiwa tertentu. Dalam konteks ini, maka hubungan dengan berbagai materi pembelajaran dan pengalaman dan hasil yang relevan harus jelas diidentifikasi.

Menurut Hasibuan (2007, p.10), manajemen sumber daya manusia adalah "Ilmu dan seni yang mengatur hubungan dan peranan tenaga kerja agar efektif dan efisien membantu terwujudnya tujuan perussahaan, karyawan, dan masyarakat. Manajemen adalah fungsi yang berhubungan dengan mewujudkan hasil tertentu melalui kegiatan orang-orang. Hal ini berarti bahwa SDM berperan penting dan dominan dalam manajemen."Keberhasilan pengelolaan organisasi sangat ditentukan kegiatan pendayagunaan SDM. Manajemen SDM diperlukan untuk meningkatkan efektifitas SDM dalam organisasi.

Hasibuan (2007, p.21) menyatakan bahwa "Fungsi manajemen SDM meliputi, perencanaan, pengorganisasian, pengarahan, pengendalian, pengadaan, pengembangan, kompensasi, pengintegrasian, pemeliharaan, kedisiplinan dan pemberhentian."

Penyusunan RPP merupakan langkah perencanaan yaitu untuk mempermudah, memperlancar, dan meningkatkan hasil proses pembelajaran. Selain itu, dengan menyusun RPP secara profesional, sistematika dan berdayaguna, maka guru akan mampu melihat, mengamati dan menganalisis serta memprediksi program pembelajaran sebagai kerangka yang logis dan terencana. RPP sebagai acuan guru melaksanakan kegiatan belajar-mengajar agar lebih terarah, berjalan secara efektif dan efesien (Mulyasa, 2011, p.213).

Pelaksanaan pembelajaran merupakan pengintegrasian proses dalam sebuah organisasi pendidikan yang pada dasarnya merupakan interaksi antara peserta didik dan sumber belajar. Guru tidak saja memberi instruksi, tetapi juga bertindak sebagai anggota organisasi belajar dan sebagai pemimpin pada lingkungan kerja yang komplek. Pembelajaran di kelas terjadi karena ada interaksi antara peserta didik dengan guru. Semua perilaku guru di dalam kelas dan di luar kelas akan mempengaruhi keberhasilan kegiatan pembelajaran. Peran utama guru di sekolah adalah melaksanakan pembelajaran sehingga guru harus menguasai materi pelajaran, mampu menyampaikan materi pelajaran kepada siswa, dan memiliki kepribadian matang (Zaenal Aqib dan Elham Rohmanto, 2008: 47). Pelaksanaan Pembelajaran terdiri dari berbagai unsur yaitu proses pelaksanaan pembelajaran, pengelolaan metode pembelajaran, dan pengelolaan media pembelajaran.

Evaluasi pengajaran dapat dikatakan sebagai salah satu proses pengendalian dalam sebuah organisasi pendidikan. Menurut Nana Sudjana (2001:27) evaluasi pengajaran merupakan suatu komponen dalam sistem pengajaran, sedangkan sistem pengajaran itu sendiri merupakan implementasi kurikulum, sebagai upaya untuk menciptakan belajar dikelas. Evaluasi pembelajaran dilakukan dengan melakukan penilaian. Penilaian menjadi alat evaluasi bagi guru ataupun sistem pendidikan untuk meningatkan pembelajaran yang lebih baik berdasarkan informasi tentang kekuatan, kelemahan yang didapatkan dari penilaian (Muijs dan Reynold, 2005, p.231). Standar penilaian pendidikan adalah standar nasional pendidikan yang berkaitan dengan mekanisme, prosedur, dan instrumen penilaian hasil belajar peserta didik. Penilaian pendidikan adalah proses pengumpulan dan pengolahan informasi untuk menentukan pencapaian hasil belajar peserta didik.

Pengaruh pendidikan dapat dilihat dan dirasakan secara langsung dalam perkembangan serta kehidupan masyarakat, juga berkontribusi sangat besar dalam kemajuan bangsa dan merupakan wahana dalam menterjemahkan pesan-pesan konstitusi, serta sarana dalam membangun watak bangsa (nation character building).

Mata Pelajaran Pendidikan Kewarganegaraan merupakan mata pelajaran yang memfokuskan pada pembentukan warganegara yang memahami dan mampu 
melaksanakan hak-hak dan kewajibannya untuk menjadi warganegara Indonesia yang cerdas, terampil, dan berkarakter yang diamanatkan oleh Pancasila dan UUD 1945. Guru memegang peranan yang sangat penting dan strategis dalam upaya membentuk watak bangsa dan mengembangkan potensi siswa dalam kerangka pembangunan pendidikan di Indonesia. Oleh sebab itu, diperlukan guru yang memiliki kemampuan yang maksimal untuk mewujudkan tujuan pendidikan nasional dan diharapkan secara berkesinambungan mereka dapat meningkatkan kompetensinya, baik kompetensi pedagogik, kepribadian, sosial, maupun profesional. Untuk menguji kompetensi tersebut, pemerintah menerapkan sertifikasi bagi guru khususnya guru dalam jabatan. Penilaian sertifikasi dilakukan secara portofolio.

Korwil Sleman Tengah terdapat 16 SMP Negeri dengan guru Pendidikan Kewarganegaraan berjumlah 22 orang. Penelitian ini akan dilakukan di tiga SMP Negeri yaitu di SMP Negeri 1, 2 dan 4 Sleman. Hal ini dikarenakan di tiga SMP tersebut memiliki prsetasi yang berbeda, SMP Negeri 1 Sleman dengan kategori prestasi tinggi, SMP Negeri 2 Sleman dengan kategori prestasi sedang dan SMP Negeri 4 Sleman dengan kategori prestasi rendah diantara 56 SMP Negeri di Kabupaten Sleman. Kategori ini antara lain berdasarkan pada hasil prestasi siswa yang diraih pada Tes Standarisasi Semester Ganjil dan Genap tahun pelajaran 2007/ 2008. Guru Pendidikan Kewarga-negaraan di tiga SMP tersebut berjumlah lima orang. Dilihat dari sumber daya manusia, latar belakang pendidikannya adalah S1, hal ini sesuai dengan kualifikasi akademik yang disyaratkan dalam Undang Undang Guru dan Dosen. Kemampuan yang dimiliki guru Pendidikan Kewarganegaraan di sekolah-sekolah tersebut berbeda-beda. Setelah mewawancarai beberapa guru Pendidikan Kewarganegaraan dan juga Kepala Sekolah mengemukakan bahwa mereka belum menggunakan metode pembelajaran yang bervariasi dan menyenangkan, hanya 20\% guru Pendidikan Kewarga- negaraan yang sering menggunakan metode-metode pembelajaran yang menarik. Data ini diperoleh melalui lembar supervisi yang dilakukan oleh Kepala Sekolah setiap satu semester. Terungkap juga bahwa beberapa guru Pendidikan Kewarganegaraan tidak membuat sendiri Rencana Pelaksanaan Pembelajaran tetapi meng-gunakan RPP yang dibuat oleh kelompok MGMP tanpa direvisi terlebih dulu, yang seharusnya hanya sekedar contoh sehingga strategi pembelajaran yang dicantumkan dalam RPP belum sesuai dengan situasi dan kondisi sekolah dari guru yang bersangkutan. Strategi pembelajaran yang dimaksudkan sudah mencakup tentang metode pembelajaran yang akan diterapkan oleh guru.

Hasil wawancara dengan beberapa guru Pendidikan Kewarganegaraan menunjukkan bahwa pada umumnya guru kesulitan menerapkan metode-metode pembelajaran yang bervariasi untuk menciptakan proses pembelajaran yang interaktif, inspiratif, menyenangkan, menantang, dan memotivasi peserta didik untuk berpartisipasi aktif. Hal ini dikarenakan beberapa hal antara lain: (1) belum/tidak menguasai macam-macam metode pembelajaran yang aktif kreatif, (2) belum menerapkan metode-metode pembelajaran yang aktif kreatif, (3) tidak mempunyai cukup waktu untuk mempersiapkan pembelajaran yang aktif dan menyenangkan, (4) sarana dan prasarana sekolah kurang mendukung, (5) menganggap bahwa dengan proses pembelajaran yang mereka lakukan siswa sudah cukup mengerti, (6) kurang menguasai teknologi sehingga belum menggunakan media elektronik baik sebagai sumber pembelajaran maupun sebagai sarana untuk proses pembelajaran. Kesulitan lain yang dihadapi adalah kurang tersedianya buku-buku teks Pendidikan Kewarganegaraan sesuai kurikulum saat ini sebagai salah satu sumber pembelajaran karena pada umumnya yang menjadi buku pegangan siswa adalah buku teks yang sudah tidak sesuai dengan kurikulum yang berlaku saat ini. 
Dari data tentang hasil belajar peserta didik untuk mata pelajaran Pendidikan Kewarganegaraan pada beberapa SMP di Korwil Sleman Tengah sejak pemberlakuan KBK 2004 serta KTSP hasil belajar peserta didik mengalami penurunan dibandingkan pada saat pemberlakuan Kurikulum 1994. Menurut wawancara dengan beberapa guru Pendidikan Kewarganegara-an, materi pelajaran PKn pada KBK 2004 dan KTSP mengalami perubahan total seiring dengan adanya reformasi sampai dengan adanya amandemen pada Undang Undang Dasar 1945. Dilihat dari materi yang relatif masih baru dan sebagian guru belum menguasai materi-materi tersebut dengan baik maka dalam menyampaikan kepada peserta didik juga kurang maksimal sehingga pada saat diadakan tes tingkat daerah hasil belajar peserta didikpun tidak sesuai harapan guru.

Pada umumnya semua guru yang diwawancarai telah melakukan penilaian tetapi belum semuanya melaksanakan analisis hasil penilaian dengan alasan tidak mempunyai cukup waktu. Ada tujuh kesalahan yang sering dilakukan oleh guru antara lain: (1) mengambil jalan pintas, (2) menunggu peserta didik berperilaku negatif, (3) menggunakan destructive dicipline, (4) mengabaikan perbedaan peserta didik, (5) merasa paling pandai, (6) tidak adil (diskriminatif), dan (7) memaksa hak peserta didik (Mulyasa, 2011: 20).

Minat, bakat, kemampuan dan potensi-potensi yang dimiliki oleh peserta didik tidak akan berkembang secara optimal tanpa bantuan guru. Dalam kaitan ini guru perlu memperhatikan perbedaan diantara peserta didik, guru diharapka memberi kemudahan belajar bagi seluruh peserta didik agar mengembangkan potensinya secara optimal. Oleh karena itu guru perlu memposisikan diri sebagai berikut: (1) orangtua yang penuh kasih sayang pada peserta didiknya, (2) teman, tempat mengadu dan mengutarakan perasaan bagi peserta didiknya, (3) fasilitator yang selalu siap memberikan kemudahan dan melayani peserta didik sesuai minat, kemampuan dan bakatnya, (4) memberi- kan sumbangan pemikiran. Mengingat kebhinekaan budaya, keragaman latar belakang dan karakteristik peserta didik, serta tuntutan untuk menghasilkan lulusan yang bermutu, proses pembelajaran untuk setiap mata pelajaran harus fleksibel, bervariasi, dan memenuhi standar. Proses pembelajaran pada setiap satuan pendidikan dasar dan menengah harus interaktif, inspiratif, menyenangkan, menantang, dan memotivasi peserta didik untuk berpartisipasi aktif, serta memberikan ruang yang cukup bagi prakarsa, kreativitas, dan kemandirian sesuai dengan bakat, minat, dan perkembangan fisik serta psikologis peserta didik.

Sesuai dengan amanat Peraturan Pemerintah Nomor 19 tahun 2005 tentang Standar Nasional Pendidikan salah satu standar yang harus dikembangkan adalah standar proses. Standar proses adalah standar nasional pendidikan yang berkaitan dengan pelaksanaan pembelajaran pada satuan pendidikan untuk mencapai kompetensi lulusan. Standar proses meliputi perencanaan proses pembelajaran, pelaksanaan proses pembelajaran, penilaian hasil pembelajaran, dan pengawasan proses pembelajaran untuk terlaksananya proses pembelajaran yang efektif dan efisien.

Berdasarkan uraian di atas maka mendorong penulis untuk melakukan penelitian lebih jauh tentang kemampuan guru dalam pembelajaran mata pelajaran PKn di SMP Negeri Korwil Sleman Tengah.

\section{Metode}

\section{Jenis Penelitian}

Jenis penelitian ini adalah penelitian kualitatif deskriptif, dengan pendekatan ini peneliti melakukan pengamatan yang cermat terhadap fenomena sosial tertentu dengan mengembangkan konsep dan menghimpun fakta, tetapi tidak melakukan pengujian hipotesis (Singarimbun dan Effendi, 1989, p.5).

Fokus penelitian ini adalah peranan guru dalam proses pembelajaran dilihat dari kemampuan guru dalam mengelola pembelajaran. Oleh karena itu penelitian 
yang dianggap lebih tepat dalam penelitian ini adalah penelitian kualitatif.

Waktu dan Tempat Penelitian

Tempat penelitian di SMP-SMP Negeri Korwil Sleman Tengah Kabupaten Sleman tengah sebanyak 16 dengan mengambil seting di tiga SMP yaitu SMP Negeri 1 Sleman dengan kategori A, SMP Negeri 2 Sleman dengan kategori $B$ dan SMP Negeri 4 Sleman dengan kategori C. Waktu penelitian bulan Januari sampai Juni 2009.

\section{Subjek dan Objek Penelitian}

Semua guru PKn sebanyak 5 orang, Kepala Sekolah 3 orang dan guru-guru mata pelajaran lain ada 9 orang dan siswa 6 orang serta pengawas 1 orang. Objek yang diteliti yaitu kemampuan guru dalam pembelajaran PKn di SMP Negeri 1 Sleman, SMP Negeri 2 Sleman dan SMP Negeri 4 Sleman.

Data, Teknik Pengumpulan Data dan Teknik Analisis Data

Teknik pengumpulan data dalam penelitian ini adalah dengan pengamatan partisipasi, wawancara mendalam, dan dokumentasi.

Keabsahan data diperoleh dengan melakukan triangulasi sumber data, yaitu dengan melakukan croscek data dari satu sumber dengan sumber lain atau dari satu teknik pengumpulan data dengan teknik pengumpulan data lainnya.

Analisis data dalam penelitian ini menggunakan analisis model kualitatifinteraktif seperti yang terdapat pada Gambar 1.

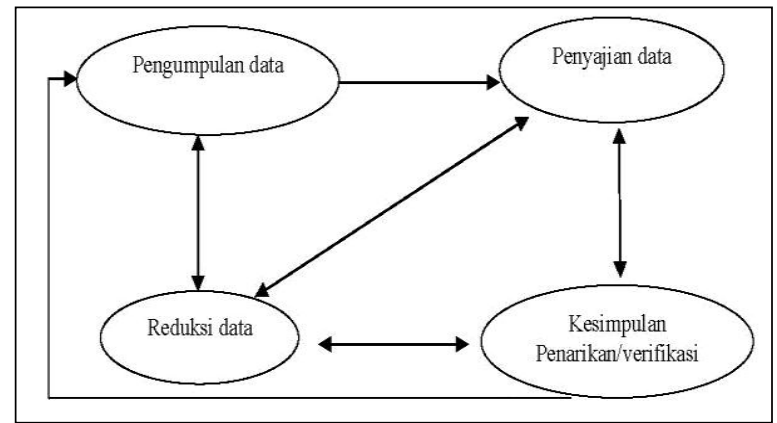

Gambar 1. Komponen Analisis Data Kualitatif Model Interaktif
Empat langkah dalam analisis kualitatif-interaktif meliputi: (1) pengumpulan data, (2) reduksi data, (3) display data dan (4) pengambilan kesimpulan.

\section{Hasil Penelitian dan Pembahasan}

Kemampuan Guru PKn dalam Kegiatan Pembelajaran

Hasil wawancara, observasi dan dokumentasi tentang kemampuan guru dipaparkan di bawah ini.

\section{Kemampuan dalam Merencanakan Pembelajaran}

Dokumentasi memperlihatkan bahwa belum semua guru menyusun RPP dengan serius. Hal ini dibuktikan dengan RPP pada satu pertemuan dengan pertemuan lain tidak menunjukkan adanya perbedaan baik dalam hal metode pembelajaran maupun pelaksanaan atau tindakan pembelajaran yang akan dilakukan. Mengenai perencanaan dalam bentuk RPP di atas juga dijelaskan oleh seorang kepala SMP di lokasi penelitian sebagai berikut:

Penyusunan RPP bagi guru merupakan sesuatu yang ideal, artinya guru PKn sebenarnya tahu dan ingin menyusun dengan sebaik mungkin. Tetapi tidak sempat karena beban pada pencapaian target pembelajaran... akhirnya guru merasa lebih utama langsung melaksanakan pembelajaran. persoalan kualitasnya nanti diuji dari kemampuan siswa menjawab tes-tes yang diberikan sekolahnya. (wawancara tanggal 01 April 2009).

Perencanaan pembelajaran dalam bentuk RPP merupakan standar yang seharusnya dijalankan oleh guru sebagai prosedur penyelenggaraan pembelajaran yang baik. Asumsinya, perencanaan pembelajaran yang baik dalam bentuk RPP akan meningkatkan kualitas proses belajar mengajar di kelas. Tetapi, perencanaan tidak harus dalam bentuk tertulis. Hal ini dikemukakan oleh salah seorang guru PKn berikut ini.

Begini tho, saya sudah mengajar bertahuntahun, selama ini saya juga belajar dari pengalaman bagaimana mempersiapkan 
pembelajaran yang lebih baik...jadi, bagaimana pembelajaran nantinya agar lebih baik dari kemarin...saya juga pikirkan, hanya saja tidak diwujudkan dalam bentuk tulisan seperti RPP... kalau RPP yang saya susun ini yaa untuk syarat formal saja (Hasil wawancara dengan guru PKn, 4 April 2009).

Perencanaan pembelajaran memang tidak harus diwujudkan dalam RPP, tetapi sebagai alat kontrol terhadap pelaksanaan pembelajaran di kelas, RPP sangat efektif. Kepala sekolah, komite sekolah atau pihak manapun dengan mudah mengetahui bagaimana pelaksanaan pembelajaran telah dilakukan dilihat dari RPP tersebut. Artinya, RPP menjadi dokumen akademik yang sangat penting bagi sekolah maupun guru.

Kemampuan guru dalam menyusun rencana pembelajaran tidak hanya dilihat dari dokumen RPP, tetapi juga dalam menguasai materi PKn, serta kesiapan guru dalam menyiapkan metode pembelajaran yang sesuai dengan karakteristik para siswa dilihat dari aspek intelektual, sosial emosional, moral, spiritual maupun latar belakang sosial budayanya. Dalam hal ini, guru PKn merasa sangat mengenal potensi siswa-siswanya serta kesulitan belajar dari para siswa.

Metode pembelajaran yang pasti digunakan adalah ceramah dan diskusi serta penugasan. Metode-metode ini dipandang lebih mudah dan praktis karena siswa tidak dibebani dengan aktivitas lain kecuali menyimak, mencatat, bertanya, serta menjawab atau memberi komentar tentang materi pembelajaran yang disampaikan oleh guru. Namun demikian, guru PKn juga mengenalkan kepada siswa dengan berbagai metode pembelajaran lain, di antaranya CTL (contextual teaching and learning), pembelajaran berkelompok, dan diskusi.

Apabila ada penugasan kelompok, kerja kelompok atau metode lain seperti CTL, maka guru sudah mempersiapkan jalannya pembelajaran di kelas. Misalnya, saat penugasan kelompok, guru sudah menyiapkan tugas dari masing-masing kelompok. Pada saat CTL, guru membuat rancangan panduan CTL yang akan digunakannya menfasilitasi siswa selama berlangsunya pembelajaran.

Media pembelajaran pada mata pelajaran PKn tidak selalu digunakan. Media pembelajaran yang tersedia di sekolah adalah berupa LCD dan proyektornya. Namun, guru hanya kadang-kadang saja menggunakan proyektor karena pembelajaran lebih sering melalui ceramah dan diskusi. Penggunaan LCD paling sering hanya 2 kali dalam sebulan.

Penguasaan guru terhadap materi PKn sangat mendukung tugas guru. Guruguru PKn di korwil Sleman Tengah berusaha melengkapi referensi atau bahan ajar dengan cara memiliki buku referensi lainnya yang berkaitan dengan PKn kelas 7,8 dan 9 SMP. Usaha ini merupakan tugas pribadi guru, dalam hal ini para guru tidak menggunakan uang dari sekolah.

Keahlian dalam menyusun rencana pembelajaran, diiringi dengan adanya komitmen para guru untuk berpegang pada rencana pembelajaran. Komitmen guru dalam hal ini baru terbatas pada komitmen normatif, artinya guru menjadikan RPP sebagai suatu bentuk kewajiban untuk membuat, menyusun RPP saja, tetapi kurang diperhatikan dalam pelaksanaan pembelajaran. Guru cenderung lebih mempertimbangkan situasi dan kondisi daripada RPP.

Fleksibilitas guru dalam merencanakan pembelajaran memperlihatkan guru tidak mau bersikap kaku. Pada kenyataannya, apa yang telah direncanakan dalam RPP tidak selalu sesuai dengan kondisi dan dinamika kelas yang terjadi. Guru menginformasikan bahwa kompetensi dasar dan standar kompetensi yang sudah ditetapkan tercapai dalam suatu proses pembelajaran memang harus dicapai, tetapi pendekatan atau metode yang diterapkan lebih bersifat situasional. Ketika suasana kelas pasif, guru mengkondisikan terjadinya diskusi kelas.

Guru bersikap terbuka ketika merencanakan pembelajaran. Misalnya, ketika ada usulan agar dilakkukan kerja kelompok, guru berusaha mengakomodir 
pendapat siswa. Dalam hal ini, guru berusaha menjadi moderator dan fasilitator bagi para siswa agar siswa lebih banyak berinisiatif dalam mempelajari PKn.

\section{Kemampuan dalam elaksanakan pembelajaran}

Kemampuan guru dalam melaksanakan pembelajaran tampak pada awal kegiatan, pada kegiatan inti maupun pada akhir pembelajaran. Dilihat dari aspek komitmen, guru selalu berpedoman pada silabus dan RPP namun dalam pelaksanaannya bersifat fleksibel sesuai dengan kondisi kelas. Hal ini menjadikan guru mampu mendinamiskan kelas.

Pada awal kegiatan, para guru memiliki gaya sendiri-sendiri ketika mengawali pembelajaran di depan kelas. Ada guru yang biasa mengajukan berbagai pertanyaan yang harus di jawab oleh para siswa, ada guru yang langsung memberikan tugas-tugas kepada siswa, ada pula guru yang membuka pembelajaran dengan mengajak siswa untuk mendiskusikan tema yang berkaitan dengan PKn.

Subjek penelitian di SMP-SMP yang diteliti memperlihatkan tingkat kemampuan yang berbeda-beda. Penilaian dari siswa-siswa dipandang lebih akurat karena siswa-siswa langsung mengalami kegiatan pembelajaran dilaksanakan. Penilaian para siswa beragam.

Dilihat dari aspek keahlian dalam melaksanakan pembelajaran, siswa-siswa di SMP A pada umumnya menilai guru telah memahami berbagai teori belajar dan prinsip-prinsip pendidikan, sebaliknya siswa-siswa di SMP B dan SMP C menilai guru tidak memahami berbagai teori belajar dan prinsip-prinsip pendidikan. Siswasiswa di SMP A dan SMP B memandang guru telah menfasilitasi perkembangan siswa, sebaliknya siswa-siswa di SMP C menilai guru belum bisa menfasilitasi perkembangan siswa.

Aspek keahlian dalam pelaksanaan pembelajaran juga tampak pada kemampuan guru menerapkan berbagai pendekatan, strategi, metode dan teknik pembelajaran secara kreatif dan kemampuan meng- gunakan media pembelajaran yang sesuai, siswa-siswa di SMP A, SMP B dan SMP C menilai guru belum menerapkan dan belum mampu menggunakan media pembelajaran. Namun, semua siswa menilai guru telah mampu berkomunikasi dengan efektif.

Uraian tersebut memperlihat bahwa kemampuan dalam pelaksanaan pembelajaran belum sepenuhnya baik. Penilaian ini memperlihatkan adanya harapan besar dari para siswa untuk mendapatkan pembelajaran yang berkualitas. Hal ini mengandung arti para guru PKn dituntut untuk meningkatkan kompetensinya, baik kompetensi pedagogik, kompetensi pribadi maupun kompetensi sosial.

Aspek keahlian dalam menerapkan metode pembelajaran masih kurang. Metode yang diterapkan selalu monoton yaitu ceramah dan diskusi. Bahkan seringkali diisi dengan kegiatan menyalin bahan ajar yang telah disiapkan oleh guru PKn. Minimnya variasi metode pembelajaran ini memperlihatkan kurangnya kreativitas guru PKn dalam mengemas kegiatan pembelajaran agar lebih menarik minat dan menumbuhkan motivasi siswa.

Pembelajaran yang monoton ini sebenarnya dapat diatasi dengan menggunakan media pembelajaran yang tepat. Media pembelajaran akan memudahkan siswa menguasi materi pelajaran. Media pembelajaran dapat berupa gambar, alat audio, visual maupun audiovisual. Media pembelaran yang sederhana seperti dengan poster atau gambar juga belum banyak digunakan oleh para guru. Para guru merasa metode ceramah dan diskusi sudah sesuai dengan kebutuhan siswa-siswanya.

Penilaian siswa tidak sepenuhnya benar jika dilihat dari pendapat kepala sekolah, maupun guru PKn sendiri. Kepala sekolah SMP C memandang pelaksanaan pembelajaran telah berjalan dengan baik dilihat dari pencapaian target pembelajaran, target waktu maupun mencapaian materinya. Kepala sekolah memang tidak melihat langsung bagaimana proses pembelajaran di kelas, tetapi melihat pencapaian hasil belajar yang tercermin pada nilai 
ulangan, mid semester ataupun ujian semester. Hal ini dinyatakan oleh salah seorang kepala sekolah berikut ini.

Saya tidak melihat langsung bagaimana pelaksanaannya, tetapi jika dilihat dari daftar nilai dan pengamatan sepintas saya percaya guru PKn telah melaksanakan pembelajaran dengan baik...meninggalkan kelas tidak pernah dilakukan, ...yaa termasuk guru yang rajin (wawancara dengan kepala sekolah SMP B).

Kemampuan guru dalam berkomunikasi di kelas, baik pada awal pembelajaran, pada kegiatan inti maupun pada akhir pelajaran menurut guru $\mathrm{PKn}$ telah berjalan dengan baik. Apabila ada siswa yang kurang memperhatikan dianggap sebagai hal yang wajar.

Observasi di kelas pada saat berlangsung proses belajar mengajar memperlihatkan fakta seperti yang dirasakan oleh para siswa. Kemampuan guru dalam melaksanakan pembelajaran masih jauh dari proses pembelajaran yang ideal. Pada awal kegiatan belajar mengajar, guru langsung membahas pada materi pelajaran, baik dengan cara mengajukan pertanyaan, berdiskusi bahkan ceramah. Batas antara kegiatan awal dan kegiatan inti tidak jelas, demikian juga dengan kegiatan akhir. Dalam hal ini siswa masih dipandang sebagai subyek pasif yang diharapkan hanya memberikan respon atas apa yang telah dilakukan oleh gurunya. Setelah guru bertanya, siswa diharapkan memberikan jawaban. Setelah guru memerintahkan sesuatu, siswa melaksanakan. Setelah guru mempersilahkan siswa mengajukan pertanyaan, siswa bertanya.

Pembelajaran di kelas belum memperlihatkan guru mampu sebagai pendidik. Pembelajaran PKn sarat dengan nilai-nilai kehidupan seperti cinta tanah air, patriotisme, dan berkarakter Pancasila. Nilainilai yang menjadi pedoman bagi siswa untuk berperilaku sebagai warga masyarakat, warga negara dan warga bangsa ini sangat penting untuk ditanamkan dalam diri siswa SMP. Dalam hal ini guru belum sampai pada tingkatan mentransfer nilainilai tersebut.
Guru lebih banyak berperan sebagai pengajar, yaitu mengajarkan pengetahuan tentang materi PKn kepada siswasiswanya. Siswa yang semula tidak tahu kemudian menjadi tahu. Peran sebagai pengajar sudah dijalankan dengan baik dilihat dari pelaksanaan pembelajaran dari awal sampai akhir kegiatan pembelajaran.

Internalisasi nilai-nilai kehidupan, pemahaman siswa terhadap materi pelajaran serta pemahaman siswa terhadap dinamika masalah kewarganegaraan membutuhkan bimbingan guru PKn. Artinya, guru PKn diharapkan dapat membimbing siswa-siswa guna menjelaskan fakta-fakta yang tidak sesuai dengan apa yang diajarkan sehingga siswa dapat memahami kenyataan yang terjadi.

Observasi di kelas memperlihatkan masih kurangnya kemampuan guru dalam memberikan bimbingan di kelas. Hal ini sangat penting karena internalisasi nilainilai ideal akan gagal apabila siswa merekam berbagai ketidakberesan dalam ketatanegaraan yang mereka dapat dari koran, televisi atau sumber lainnya. Fakta berupa korupsi, penyalahgunaan wewenang dan tindakan pelanggaran undangundang begitu jelas diberitakan oleh berbagai media. Fakta ketidakberesan ini tentu akan mengusik pikiran siswa yang harus mendapatkan penjelasan dari guru tentang mengapa hal tersebut terjadi dan bagaimana seharusnya siswa menyikapinya.

Guru dituntut memiliki keterampilan lain yang dapat mendukung kemampuannya dalam mengajar. Dalam hal ini dibutuhkan keterampilan guru. Penanaman nilai-nilai yang terkandung dalam PKn juga membutuhkan kemampuan guru untuk peka dengan aspirasi siswa-siswa. Dalam hal ini profesional guru dilihath dari aspek keterampilan dalam mengajar memperlihatkan telah bersedia mendengar pendapat siswa, bersifat terbuka pada masukan/kritik dari siswa, menjadi moderator yang baik ketika terjadi diskusi atau perbedaan pendapat serta menjadi fasilitator yang baik bagi siswa-siswanya. 
Guru perlu melatih kepekaan atau kepedulian siswa untuk mengambil tindakan yang tepat untuk merespon berbagai persoalan yang mereka tangkap dari media massa. Observasi di kelas memperlihatkan bahwa guru tidak mengajak siswa-siswanya untuk mendiskusikan fakta-fakta di atas. Hal ini ditegaskan dalam kutipan wawancara berikut.

Kalau mendiskusikan tentang berbagai masalah seperti korupsi, tindakan demonstrasi, konflik antara para penyelenggara negara, dan sebagainya pasti membutuhkan waktu yang lebih lama lagi. Dengan waktu yang ada, materi yang ada di buku saja kadang tidak dapat tuntas (hasil wawancara dengan guru PKn tanggal 6 April 2009).

Bagi siswa-siswanya, guru adalah sosok yang sudah selayaknya ditiru atau diteladani. Berkaitan dengan ini, guru dituntut mampu menampilkan keteladanannya di hadapan siswa. Keteladanan yang dimaksudkan dalam tulisan ini adalah keteladanan dalam menyikapi berbagai persoalan di masyarakat maupun di sekolah. Hasil wawancara dengan guru-guru lainnya memperlihatkan keteladanan guru PKn masih kurang. Demikian juga dalam memberikan bimbingan kepada siswasiswanya seperti terungkap dalam kutipan berikut:

Langka ada guru ideal. Guru PKn sama dengan guru-guru yang lainnya lebih menyadari guru sebagai tugas berkaitan dengan proses belajar. Kalau tuntutan dalam konsep guru ideal, kan guru menjadi seperti malaikat. (hasil wawancara dengan guru non PKn tanggal 6 April 2009).

Keberhasilan guru dalam melaksanakan pembelajaran sangat membutuhkan kompetensi pribadi maupun kompetensi sosial guru-guru PKn. Kepedulian guru terhadap berbagai persoalan ketatanegaraan dan kewarganegaraan sudah seharusnya direspon secara spontan, tepat dan bijak. Untuk itu, tanpa adanya kompetensi pribadi dan kompetensi sosial yang memadai, maka guru PKn hanyalah se- bagai pengajar yang hanya sekedar memberikan sejumlah pengetahuan kepada siswa-siswanya.

Hasil wawancara dengan sejumlah guru PKn, guru lain dan kepala sekolah memperlihatkan bahwa kompetensi pribadi guru PKn pada umumnya sudah baik. Kompetensi ini tercermin pada keterampilan guru dalam menjalanakn pembelajaran yang meliputi (1) menghargai siswa tanpa membedakan agama, suku, adat, gender dan asal daerah, (2) bersikap sesuai dengan norma-norma yang berlaku di masyarakat, (3) jujur, tegas dan manusiawi, (4) berperilaku yang mencerminkan ketaqwaan dan akhlak mulia dan (5) tampil sebagai pribadi yang mantap dan stabil

Beberapa aspek yang dirasa belum sesuai adalah guru belum berperilaku yang dapat diteladani dan guru belum menampilkan diri sebagai pribadi yang dewasa, arif, dan berwibawa. Hal ini memperlihatkan bahwa guru PKn sendiri belum sepenuhnya percaya diri bahwa dirinya layak diteladani dan mampu bersikap arif dan berwibawa. Pendapat ini juga sejalan dengan pandapat guru-guru lain maupun kepala sekolah. Ketidakpercayaan diri terhadap kemampuan diri, pemikiran atau pendapatnya menjadikan guru bersangkutan ragu-ragu untuk menyampaikannya kepada siswa.

Kompetensi sosial guru PKn pada umumnya sudah baik. Kompetensi pribadi guru PKn yang dipandang sudah dimiliki guru PKn yaitu: (1) bersikap inklusif dan obyektif terhadap siswa, teman sejawat, dan lingkungan sekitarnya, (2) beradaptasi dengan lingkungan tempat kerjanya dalam rangka meningkatkan efektifitas sebagai pendidik, (3) tidak bersikap diskriminatif terhadap orang tua siswa, siswa, teman sejawat dan lingkungan, (4) berkomunikasi secara santun, empatik dan efektif dengan teman sejawat.

Aspek kompetensi sosial yang belum dimiliki guru PKn, menurut penilaian guru-guru lain dan kepala sekolah yaitu: (1) berkomunikasi secara santun, empatik dan efektif dengan orang tua siswa dan masyarakat berkaitan dengan 
kemajuan siswa, (2) mengikutsertakan orang tua dan masyarakat dalam mengatasi kesulitan belajar siswa, (3) mengkomunikasikan hasil inovasi belajar kepada teman seprofesi, dan (4) melaksanakan program/kegiatan yang memajukan pendidikan di daerahnya.

Hal tersebut memperlihatkan bahwa guru PKn belum sepenuhnya menjalin komunikasi secara memadai dengan orang tua siswa dan teman seprofesi guna meningkatkan kualitas belajar PKn. Observasi di sekolah memperlihatkan kompetensi sosial guru PKn masih kurang dilihat dari adaptasinya dengan lingkungan kerjanya guna meningkatkan kualitas dirinya sebagai pendidik.

Komitmen guru dalam pelaksanaan pembelajaran tampak dari dimilikinya sejumlah referensi bahan ajar yang memadai. Selain berpegang pada buku paket, guru juga mempelajari bahan ajar dari berbagai penerbit dan referensi lain yang mendukung. Guru menunjukkan referensi yang dimilikinya dan menperlihatkan kepada para siswa untuk juga membaca dari berbagai sumber, tidak hanya dari buku paket.

Kemampuan guru dalam pelaksanaan pembelajaran tampak dari ketegasan guru menerapkan tata tertib di kelas. Meskipun guru akomodatif dalam merencanakan atau memutuskan pendekatan pembelajaran, tetapi guru tegas pada tujuan dan target untuk mencapai kompetensi yang ditetapkan dalam RPP.

Keahlian dan komitmen guru dalam pelaksanaan pembelajaran ditunjang dengan keterampilan lain yang dimiliki sebagian guru PKn. Keterampilan yang dimaksud yaitu keterampilan berkomunikasi dengan siswa-siswa. Misalnya, pada saat pembelajaran guru aktif merangsang daya pikir siswa dengan melemparkan pertanyaan ataupun mengembalikan pertanyaan kepada siswa lain agar menjawab. Dalam hal ini, guru tidak melihat pada benar atau salahnya, tetapi lebih menghargai pada sikap dan proses yang dilalui siswa. Sikap guru seperti ini dipandang dapat memotivasi para siswa.
Kemampuan dalam Melaksanakan Penilaian pembelajaran

Penilaian pembelajaran menurut para guru PKn telah dilaksanakan dengan baik. Penilaian dilakukan dengan menggunakan instrumen berupa ulangan harian, penugasan, tes mid semester, maupun tes semester. Guru PKn cukup ahli dalam melakukan evaluasi berkala, guru mampu membuat butir-butir soal, dan guru dapat menghargai proses. Guna mengetahui kompetensi siswa, guru juga memberi tugas kepada para siswa secara proporsional.

Penilaian juga dilakukan melalui pengamatan selama proses belajar mengajar. Pengamatan dilakukan menggunakan ceklis, tetapi dicatat oleh guru sebagai bahan pertimbangan untuk menambah nilai raport. Terkait dengan penilaian, guru PKn mempelihatkan komitmen untuk melakukan evaluasi sesuai dengan prinsipprinsip penilaian. Berdasarkan wawancara dengan sejumlah guru PKn memperlihatkan bahwa seluruh aspek penilaian telah dilaksanakan, yaitu: (1) memahami prinsip-prinsip penilaian dan evaluasi, (2) menentukan aspek-aspek proses dan hasil yang akan dievaluasi, (3) menentukan prosedur penilaian dan evaluasi, (4) mengembangkan instrumen, (5) mendokumentasikan hasil penilaian dan evaluasi, (6) menganalisis hasil penilaian dan evaluasi dan (7) melakukan proses evaluasi dan hasil.

Mengenai aspek-aspek proses yang dinilai telah disiapkan oleh guru. Biasanya, guru menentukan bagian mana yang akan diberikan penilaian seperti dikemukakan dalam kutipan wawancara berikut.

Sebelum diadakan ulangan harian, saya mengumumkan terlebih dulu...bab ini sampai bab ini dipelajari...besok akan diadakan ulangan. Demikian juga pada saat menghadapi mid semester, saya menyampaikan apa saja yang sebaiknya dipelajari. (wawancara dengan guru PKn, 7 April 2009).

Hampir semua guru PKn menyatakan diri telah melaksanakan penilaian ter- 
hadap pembelajaran yang telah dilakukan. Tetapi, kegiatan penilaian selama ini lebih banyak dilakukan terhadap kemampuan siswa dalam menyerap materi pelajaran. Artinya, evaluasi tidak mencakup proses belajar mengajar. Evaluasi lebih banyak ditekankan pada hasil belajar.

Pemanfaatan hasil penilaian dan evaluasi, yaitu: untuk menentukan ketuntasan belajar, meningkatkan kualitas pembelajaran, merancang program remedial dan pengayakan dan sumber informasi bagi stakeholders.

Berkaitan dengan penentuan ketuntasan belajar, guru PKn telah mengacu pada standar kompetensi dan kompetensi dasar yang harus dikuasai oleh siswa. Guru PKn juga telah menetapkan KKM (kriteria ketuntasan minimal) yang harus dicapai oleh siswa. Hasil penilaian akan menginformasikan sejauhmana ketuntasan minimal telah tercapai. Apabila ada yang masih di bawah KKM atau dinilai masih kurang, maka guru PKn memberikan kesempatan kepada siswa-siswa untuk meningkatkan nilai belajarnya dengan memberikan remedial berupa penugasan kepada siswa yang nilainya masih di bawah KKM. Hasil penilaian juga menginformasikan kepada guru dan sekolah tentang bagaimana merancang pembelajaran agar menghasilkan pencapaian hasil belajar yang lebih baik lagi.

Hambatan-hambatan yang Dihadapi Guru dalam Melaksanakan Kegiatan

Pembelajaran.

Hambatan yang dihadapi guru dapat bersumber dari internal guru sebagai fasilitator belajar atau dari eksternal yaitu dari luar guru PKn yang diuraikan sebagai berikut.

\section{Hambatan internal}

Hambatan internal yang dihadapi guru PKn dalam pelaksanaan pembelajaran di antaranya adalah keterbatasan wawasan, rendahnya motivasi, rendahnya komitmen dan pengalaman guru PKn. Berbagai hambatan internal tersebut ada yang diakui dan disadari oleh guru PKn ada pula yang tidak. Data tentang hambatan internal didapatkan dari observasi di kelas serta wawancara kepada guru PKn, guru lain, kepala sekolah dan siswa.

Keterbatasan wawasan atau pengetahuan dirasakan oleh guru PKn karena materi pendidikan kewarganegaraan sangat luas dan terus berkembang. Hal ini menuntut guru PKn untuk banyak membaca dan mencari informasi lebih luas. Tetapi guru PKn mengaku kesulitan untuk mendapatkan bahan bacaan yang tepat dan lengkap. Salah seorang guru PKn mengatakan:

Kalau dituruti, banyak buku yang harus dibaca...dipelajari karena materi PKn untuk SMP tidak seperti di SD. Materi di SMP menuntut guru dan siswa harus selalu mengikuti perkembangan di luar. Kalau materi matematika kan jelas itu-itu terus...PKn lain lagi.. (hasil wawancara dengan guru PKn tanggal 9 April 2009).

Observasi menemukan fakta bahwa keterbatasan wawasan terlihat oleh ketidakmampuan guru menjelaskan tentang hubungan antara pemerintah daerah dan pusat ketika terjadi konflik. Ketika guru menerangkan tentang globalisasi kaitannya dengan pasar bebas dan sikap masyarakat Indonesia, guru tampak kurang menguasai persoalan.

Sebenarnya, sumber bahan ajar sangat banyak yang dapat diakses dengan jauh lebih murah yaitu dengan memanfaatkan fasilitas internet. warung internet saat ini telah menjamur sehingga mudah dijangkau. Bahkan di sekolah juga sudah ada yang memiliki jaringan internet sendiri. Tetapi tidak banyak guru PKn yang memanfaatkan jaringan internet ini. Hal ini memperlihatkan masih lemahnya kreativitas guru untuk mencari bahan ajar. Guru lebih memilih mempelajari apa yang sudah tersedia di sekolah atau sudah ada di pikiran guru daripada harus mencari halhal baru.

Kondisi kurang kreatifnya guru mencari sumber bahan ajar sejalan dengan lemahnya motivasi guru. Guru lebih tertarik untuk mendahulukan kegiatan yang menghasilkan tambahan penghasilan dari- 
pada meningkatkan pengetahuan atau wawasannya. Berkaitan dengan motivasi guru, hasil wawancara dari siswa SMP B memperlihatkan bahwa sebenarnya guru memiliki motivasi yang baik dilihat dari kedisiplinan, dan kesiapan dalam mengajar sebagaimana dikemukakan dalam kutipan berikut.

Guru PKn di sini sudah baik. Kalau mengajar menyenangkan...santai...jadi nggak terlalu serius begitu...kalau santai kan teman-teman juga betah (hasil wawancara dengan siswa tanggal 10 April 2009).

Ungkapan di atas menunjukkan adanya perbedaan indikator yang digunakan siswa dalam menilai kualitas gurunya. Siswa lebih memilih kegiatan belajar yang santai dan menyenangkan.

Komitmen guru terhadap tugastugasnya sebagai pendidik dinilai masih kurang. Hal ini tampak dari masih rendahnya motivasi guru untuk mengikuti kegiatan pengembangan profesi baik melalui MGMP, penataran, seminar atau kegiatan sejenisnya.

Banyaknya guru-guru, termasuk guru PKn yang rajin mengikuti berbagai kegiatan seminar, penataran atau worksop belum memperlihatkan adanya pengaruh nyata terhadap peningkatan kualitas pembelajaran. Hal ini dapat terjadi karena sebagian besar guru PKn lebih tertarik pada pengumpulan portofolio guna memenuhi persyarakatan untuk sertifikasi guru.

Hambatan dalam menjalankan kemampuan guru diukur dari kesesuaian kualifikasi akademik guru PKn, pendidikan dan pelatihan yang diikuti, serta pengalaman mengajarnya. Guru PKn yang tidak memiliki latar belakang pendidikan PKn akan kesulitan mengajar. Temuan di lokasi penelitian memperlihatkan bahwa semua guru PKn memiliki latar belakang pendidikan guru bidang studi PKn.

Guru-guru PKn di Korwil Sleman telah mengikuti pendidikan dan pelatihan seperti pelatihan pengembangan bahan ajar sampai kepada latihan menyusun RPP. Temuan di lokasi penelitian memperlihatkan tidak ada hambatan dari diklat.
Keikutsertaan guru PKn ke berbagai forum ilmiah seperti seminar memperlihatkan kesediaan guru PKn untuk mengembangkan kemampuannya sebagai guru.Keikutsertaan guru ini sedikit banyak memaksa guru untuk mempelajari kembali praktik mengajar yang biasa mereka jalankan dengan konsep-konsep baru yang didapat dari forum-forum ilmiah. Keikutsertaan guru ini pada akhirnya akan menambah pengalaman guru. Pada kenyataannya, pengalaman guru masih kurang walaupun masa kerja guru cukup lama.

\section{Hambatan eksternal}

Hambatan eksternal yang dihadapi guru dalam menjalankan kegiatan pembelajaran di antaranya adalah keterbatasan sarana prasarana, keterbatasan bahan ajar, kesiapan siswa dalam menyiapkan diri mengikuti kegiatan belajar mengajar, dan rendahnya motivasi siswa. Sarana prasarana pembelajaran PKn di sekolah relatif sangat terbatas. Hal ini tampak pada minimnya simbol-simbol, gambar peta dan media pembelajaran berupa audiovisual. Media pembelajaran tidak hanya memudahkan siswa dalam menguasai sutau materi pelajaran, tetapi juga dapat menarik minat dan motivasi siswa untuk mengikuti kegiatan belajar mengajar.

Bahan ajar berupa referensi dan buku PKn terbatas hanya berupa buku paket dan LKS (Lembar Kerja Siswa) yang berisi ringkasan materi dan latihan-latihan soal. Buku pendukung PKn memang ada di perpustakaan, tetapi jumlahnya di masing-masing sekolah tidak lebih dari 20 buah. Dengan demikian, siswa-siswa yang membutuhkan buku tersebut harus bergantian. Karena terbatas jumlahnya, maka guru juga sangat jarang menggunakan buku tersebut.

Gambar peta berupa peta nasional, peta regional ataupun peta dunia sudah tersedia di kelas atau di ruang guru. Tetapi media ini sangat jarang digunakan. Bahkan ada guru PKn yang sama sekali tidak menggunakan media pembelajaran. Padahal, media gambar dapat mengaktifkan indra penglihatan agar siswa lebih aktif. 
Pembelajaran dengan menggunakan audiovisual juga tidak pernah dilakukan. Belajar dengan media audivisual tidak dilakukan karena guru merasa bahwa cara lama lebih mudah dan sederhana dibuktikan siswa mudah memahami pelajaran seperti dikatakan oleh guru PKn berikut.

Bagus juga menggunakan media audiovisual karena siswa pasti lebih tertarik bisa melihat gambar, bisa mendengar tentang materi yang dipelajari. Tetapi tertarik saja tidak menjamin siswa menguasai lho. Saya selama ini tidak menggunakan media itu walaupun di sekolah ini juga ada. Saya tidak melakukan karena memang belum membutuhkan. Dengan ceramah dan diskusi saja, siswa-siswa mudah memahami materinya. (hasil wawancara dengan guru PKn tanggal 1 April 2009).

Hal ini menegaskan bahwa pembelajaran dengan ceramah dan diskusi lebih efisien dan efektif dalam menguasai pelajaran. Tetapi menurut para siswa, pembelajaran melalui ceramah diikuti dengan mencatat atau menyalin telah menimbulkan kebosanan. Pelajaran PKn menjadi tidak menarik dan tidak memiliki bobot tertentu.

Pembahasan

Kemampuan Guru PKn dalam Kegiatan Pembelajaran

Kegiatan pembelajaran membutuhkan adanya perencanaan pembelajaran. Perencanaan ini diwujudkan dalam pembuatan RPP. Hasil temuan di atas memperlihatkan bahwa RPP hanya menjadi syarat administrasi atau sebagai dokumen sekolah. Guru-guru PKn membuat RPP ala kadarnya membuktikan bahwa guru PKn mempersepsikan RPP secara keliru. RPP yang tidak disusun secara serius ini pada akhirnya mempengaruhi kemampuan guru dalam menyiapkan bahan ajar pada setiap kali pertemuan. Guru hanya menyiapkan bahan berdasarkan apa yang ada di dalam pikiran atau ingatannya saja.

Proses pembelajaran sebenarnya tidak hanya terbatas pada masalah transfer pengetahuan, tetapi juga transfer nilai. Dalam konteks ini, guru harus memahami karakteristik siswa, kemampuan awal ketika mengikuti pelajaran dan sebagainya. Semua itu harus terdokumentasikan dengan baik agar proses pembelajarn dari waktu ke waktu selalu dapat dipantau dan dievaluasi.

Kemampuan guru dalam kegiatan pembelajaran yang tampak pada saat menjalankan kegiatan belajar mengajar di kelas terlihat pada kegiatan awal, kegiatan inti maupun kegiatan di bagian akhir pembelajaran. Pada aspek ini, kemampuan guru sudah berjalan dengan baik meskipun belum sepenuhnya sesuai dengan kebutuhan siswa. Dalam hal ini siswa tidak hanya membutuhkan pengembangan kompetensi kognitif, tetapi juga kompetensi afektif. Artinya, siswa membutuhkan suatu makna atas apa yang dipelajarinya yang didapat dari pemahaman siswa tentang mengapa sesuatu harus dipelajari.

Siswa lebih apresiatif terhadap kegiatan belajar mengajar ketika dalam diri siswa telah terbangun suatu persepsi bahwa PKn merupakan pelajaran yang menarik, perlu dipelajari, bahkan menjadi kebutuhan. Untuk itu, guru sudah seharusnya sejak awal mampu menarik perhatian para siswa utuk belajar dengan penuh semangat.

Deporter, Reardon dan Nourie (2001: 88) mengemukakan cara menjadikan siswa tertarik dan berminat pada pelajaran melalui 6 langkah yaitu: tumbuhkan, alami, namai, demonstrasikan, ulangi, dan rayakan. Maksud 'tumbuhkan' adalah mengajak para siswa untuk mencari tahu manfaat apa yang didapat siswa dari mempelajari suatu pelajaran. Apabila siswa sudah mengetahui manfaat untuk dirinya, maka siswa cenderung lebih mudah diajak untuk menjadikan belajar sebagai pengalaman mereka sehingg belajar menjadi lebih bermakna. Kata 'alami' dimaksudkan untuk mengajak siswa menjalani proses belajar. Kata 'namai' mengandung maksud bahwa ketika siswa sudah muncul minatnya, maka siswa ditunjukkan data atau fakta-fakta yang ingin mereka ketahui. Kata 'demonstrasikan' mengandung maksud bahwa setiap siswa didorong untuk meng- 
kaitkan fakta-fakta tersebut dengan pengalaman pribadi atau kehidupan sehari-hari siswa. Kata 'ulangi' mengandung maksud para siswa didorong untuk menyebutkan kembali atau menyimpulkan pengetahuan yang baru didapatnya. Kata 'rayakan' mengandung maksud siswa-siswa diajak untuk menegaskan atau menguatkan pemahaman baru tersebut dengan kalimat atau ungkapan-ungkapan yang memotivasi.

Minat siswa untuk mempelajari mata pelajaran PKn erat kaitannya dengan kemampuan guru PKn dalam memilih pendekatan pembelajaran dan kemampuan guru PKn dalam menumbuhkan minat siswa. Tumbuhnya minat belajar berarti adanya motivasi belajar. Karena itu, minat siswa dapat ditumbuhkan dengan memberikan motivasi-motivasi kepada para siswa.

Penilaian terhadap hasil belajar ditempuh dengan mengadakan ulangan harian, mid semester maupun ujian semester. Penilaian ini membutuhkan keterampilan guru dalam menyusun instrumen evaluasi. Berdasarkan temuan penelitian, kemampuan guru-guru PKn dalam menyusun instrumen sudah baik.

Keseluruhan kegiatan pembelajaran sampai kepada kegiatan penilaian membutuhkan kemampuan guru sebagai pendidik, pengajar, pembimbing, pelatih, pembaru, teladan, pribadi, pembangkit semangat dan sebagainya. Dilihat dari berbagai kemampuan tersebut, guru PKn masih jauh dari ideal.

\section{Hambatan-hambatan yang Dihadapi Guru dalam Melaksanakan Kegiatan Pembelajaran.}

Masalah internal seperti keterbatasan wawasan, motivasi, dan komitmen dapat diminimalisir apabila ada keterbukaan komunikasi antara guru PKn dengan teman sejawat atau dengan kepala sekolah.

Komitmen profesi guru harus dilihat dari komitmen guru terhadap profesinya, komitmen terhadap murid-muridnya, komitmen kepada kolega dan komitmen terhadap institusi atau sekolahnya. Komitmennya terhadap profesi ditunjukkan dengan kerja keras untuk membangun kepercayaan diri dan etika profesinya, serta terus mengembangkan keutuhan dan keharmonisan dalam dirinya dengan masyarakat luas. Karena itu, guru yang memiliki komitmen professional sudah seharusnya selalu mendorong tercapainya pelayanan professional sesuai dengan standar profesi yang telah ditetapkan guna meningkatkan mutu pendidikan.

Komitmen pada murid-murid ditunjukkan dengan membantu muridmuridnya untuk mendapatkan suatu kemampuan yang lebih baik dan efektif sebagai anggota masyarakat. Upaya ini membutuhkan kemampuan personal dalam mengembangkan moral, intelektual, fisik, social dan estetika murid-muridnya. Guru harus memberikan kesempatan belajar yang sama bagi semua muridmuridnya dan membangun kepercayaan diri pada murid serta hubungan saling percaya antara guru dan murid-muridnya.

Komitmen terhadap kolega ditunjukkan dengan sikap yang penuh perhatian, saling memberikan dukungan dalam menjalankan tugas-tugas profesional dan bersikap responsif terhadap koleganya. Salah satu pengembangan profesional dilakukan dengan sharing gagasan atau informasi dengan sesama kolega serta menjaga hubungan yang harmonis.

Berbagai hambatan internal ini tidak seluruhnya diketahui oleh kepala sekolah sebagai manajer pendidikan. Hal ini dapat dipecahkan dengan cara meningkatkan kompetensi guru PKn dalam bidang profesinalisme, dalam bidang pembelajaran, serta kompetensi kepribadian dan sosial.

\section{Simpulan dan Saran}

Simpulan

Beberapa kesimpulan yang dapat dikemukakan berdasarkan hasil dan pembahasan penelitian ini adalah:

Pertama, kemampuan guru Pendidikan Kewarganegaraan di SMP Negeri Korwil Sleman Tengah dalam pembelajaran masih kurang. Hal ini tampak dari kemampuan guru dalam merencanaan 
pembelajaran. Penyusunan RPP yang belum dilakukan secara serius. Pelaksanaan pembelajaran lebih banyak didasarkan pada kebiasaan guru dalam mengajar sehari-hari. Selama dalam kegiatan pembelajaran, guru belum dapat memainkan berbagai peran yang dibutuhkan oleh siswa seperti peran guru sebagai pendidik, inovator, teladan dan sebagainya.

Penilaian guru terhadap pencapaian hasil belajar dilakukan oleh masingmasing guru PKn dalam bentuk ulangan harian. Sekolah mengadakan penilaian melalui ujian mid semester maupun ujian semesteran. Dalam melakuan penilaian, guru PKn belum terbiasa mengembangkan instrumen penilaian.

Kedua, hambatan internal meliputi masih terbatasnya wawasan pengetahuan guru PKn terutama wawasan terhadap segala hal yang berkaitan dengan materi PKn, masih lemahnya motivasi guru untuk mempelajari berbagai bahan ajar yang mendukung, serta belum kuatnya komitmen guru PKn dalam melaksanakan tugas guru baik sebagai pendidik, pengajar, teladan, inovator maupun sebagai pribadi. Hambatan internal lainnya adalah terbatasnya pengalaman guru dalam mengikuti berbagai forum ilmiah secara serius.

Hambatan eksternal yang dihadapi guru PKn adalah masih terbatasnya media pembelajaran yang ada di sekolah. Media pembelajaran yang ada selama ini dipandang oleh para guru kurang menarik untuk ditampilkan di kelas. Keterbatan yang ada di sekolah adalah terbatasnya sumber bahan ajar.

Saran

Bagi Dinas Pendidikan Kabupaten Sleman, sebaiknya memberikan pembinaan pengembangan kurikulum sampai kepada keterampilan menyusun RPP guna mengetahui konsistensi RPP dengan pelaksanaannya di kelas.

Bagi sekolah, sebaiknya lebih banyak memberikan dorongan atau motivasi kepada guru PKn agar terus mengembangkan kompetensinya dengan cara mendatangi berbagai forum ilmiah.
Bagi guru PKn, sebaiknya terus meningkatkan kompetensinya dengan cara memanfaatkan berbagai media pembelajaran termasuk dengan memanfaatkan sumber belajar dari internet agar tidak tertinggal oleh dinamika materi yang berkaitan dengan pendidikan kewarganegaraan.

\section{Daftar Pustaka}

Chambers, P. (2008). Teaching mathematics, developing as a reflective secondary teacher. California: Sage publication

Cheng, T.C, Tam, W.M. \& Tsui K.T, (2002). New conceptions of teacher effectiveness and teacher education in the new centur, Hong kong Teachers' Centre Journal, Vol. 1, Spring 2002, page 1 - 19

Enco Mulyasa. E. (2011). Kurikulum tingkat satuan pendidikan. Bandung: Remaja Rosdakarya

Muijs, D. \& Reynolds, D. (2005). Effective teaching, efidence and practice. London: Sage Publication.

Nana Sudjana (2001). Penilaian hasil proses belajar mengajar. Bandung: Rosdakarya

Samsuri, (2011). Model pembelajaran pendidikan kewarganegaraan untuk membangun kompetensi warga negara, makalah kuliah umum di Program Studi Pendidikan Pancasila dan Kewarganegaraan (PPKn) FKIP Universitas Ahmad Dahlan, Yogyakarta, 9 Mei 2011

Singarimbun, M. dan Effendi, S., ed (1989) Metode penelitian survei. Pustaka. LP3ES Indonesia

Training and Development Agency for Schools', (2007), Professional standards for teachers core, dalam http://www.rbkc.gov.uk/pdf/stan dards_core.pdf, diakses tanggal 12 April 2013.

Wina Sanjaya (2009). Stategi Pembelajaran berorientasi standar proses pendidikan. Jakarta:Kencana.

Zaenal Aqib dan Elham Rohmanto (2008). Membangun profesionalisme guru dan pengawas sekolah. Bandung: Yrama Widya. 